\title{
The SAVI Learning Model Application Assisted by E-Learning-Based Accounting Puzzle Media to Improve Vocational School Students' Collaboration Skills
}

\author{
Vinky Febriyani Cahya Putri ${ }^{1}$, Sri Sumaryati2 Jaryanto $^{3}$ \\ vinkyfebriyanicp@student.uns.ac.id¹ , srisumaryati@staff.uns.ac.id², jaryanto_uns@yahoo.com³
}

\begin{abstract}
: 21st-century learning requires a variety of skills that must be mastered by students, one of which is collaboration skills. Reality showed that AKL Class $X$ students' collaboration skills in Wikarya Karanganyar Vocational School were in the not good category, amounting to $43,52 \%$. This study aims to obtain empirical evidence that the SAVI learning model application assisted by e-learning-based Accounting Puzzle media could improve the collaboration skills of class X AKL in Wikarya Vocational High School Karanganyar students. This research was a Classroom Action Research conducted in two cycles, consisting of four stages: action planning, action implementation, observation, and reflection. Data collection techniques used observation, interviews, and documentation. Data analysis employed qualitative data and quantitative data. This study determined the achievement indicator for collaboration skills' success by $62,5 \%$, classified in the good category. In the preaction, the percentage of collaboration skill indicators was $43,52 \%$ in the not good category; the first cycle increased to $57,72 \%$ in the sufficient category; the second cycle also increased to $72,84 \%$ in the good category. Based on this research, the SAVI learning model assisted by e-learning-based Accounting Puzzles media could improve collaboration skills.
\end{abstract}

Keywords: $\quad$ SAVI based on e-learning, Accounting Puzzles, collaboration skills

Abstrak: Keterampilan kerjasama peserta didik kelas $X$ AKL di SMK Wikarya Karanganyar dalam kategori tidak baik, sebesar 43,52\%. Tujuan penelitian ini adalah untuk memperoleh bukti empiris bahwa penerapan model pembelajaran SAVI berbantuan media Teka-Teki Akuntansi berbasis e-learning dapat meningkatkan keterampilan kerjasama peserta didik kelas X AKL SMK Wikarya Karanganyar. Penelitian ini merupakan Penelitian Tindakan Kelas dilaksanakan dalam dua siklus meliputi empat tahap, yaitu: perencanaan tindakan, pelaksanaan tindakan, observasi, dan refleksi. Teknik pengumpulan data menggunakan observasi, wawancara, dan dokumentasi. Analisis data menggunakan data kualitatif dan data kuantitatif. Penelitian ini menetapkan indikator capaian keberhasilan keterampilan kerjasama sebesar 62,5\%, termasuk dalam kategori baik. Pada pra tindakan diperoleh persentase indikator keterampilan kerjasama sebesar 43,52\%, kategori tidak baik, siklus I mengalami peningkatan menjadi $57,72 \%$ kategori cukup, dan siklus II juga mengalami peningkatan, menjadi 72,84\%, kategori baik. Berdasarkan penelitian ini, model pembelajaran SAVI berbantuan media Teka Teki Akuntansi berbasis e-learning dapat meningkatkan keterampilan kerjasama.

Kata Kunci: $\quad$ SAVI berbasis e-learning, Teka Teki Akuntansi, keterampilan kerjasama

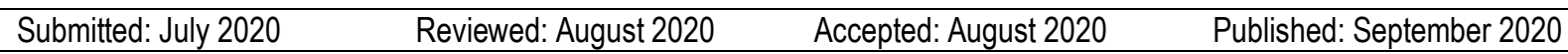

\footnotetext{
1 Universitas Sebelas Maret

2 Universitas Sebelas Maret

3 Universitas Sebelas Maret
} 


\section{INTRODUCTION}

C ollaboration skills are essential skills for achieving effective and meaningful learning in terms of interacting with others to accomplish common goals by respecting each member's differences, participating in discussions, making decisions, and supporting others. Greenstein (Redhana, 2012) said that collaboration skills in the classroom could occur when students work to divide tasks to achieve common goals, engage in task completion, and share initial knowledge to generate ideas. Collaboration skills are one of the learning skills that students must have to face 21st-century challenges. Based on the Sumaryati, Joyoatmojo, Wiryawan, \& Suryani's research (2020), collaboration skills and problem-solving skills are the most important skills because students' ability to solve problems is better when done together rather than individually. Daryanto \& Karim (2017) stated that collaboration skills could improve group collaboration and determine social relations' success in society. Therefore, learning activities are not just activities of transferring material from teachers to students, but creating positive interactions between students and teachers to be meaningful and able to carry out an activity together (Sholihin, 2015). Collaboration skills provide benefits to students to give and appreciate each other. It also avoids selfish attitudes and individual attitudes to students because, in fact, humans cannot live alone without others' help. Besides, collaboration skills can help students attain learning goals by working together in a group to get much knowledge. Currently, collaboration skills are the key to success in social life (Redhana, 2019).

Based on observations in class X AKL SMK Wikarya Karanganyar, students' collaboration skills were low. It was indicated by several problems: 1) the discussion process did not run optimally to solve problems, 2) students in groups were passive and more comfortable when working on group assignments individually, 3) when delivering the discussion results, most students ignored to friends in front of the class, 4) mutual respect and appreciation among students were lacking, 5) students were hesitant and afraid to express opinions, and 7) embarrassed to ask the teacher when experienced difficulty.

In connection with the above problems, one alternative problem-solving that can be done is implementing a collaborative and active learning model, utilizing all senses to attain meaningful learning, namely by the SAVI learning model (Reningsih, 2013; and Zulfa, 2013). The SAVI learning model has four characteristics, each of which shows an indicator of student collaboration skills, including somatic. It can be seen when students practice doing questions, join online classes to follow learning from teachers, and present discussion results. Auditory is seen when students can provide opinions and respect for friends' opinions. Visuals are seen when students pay attention to friends or teachers talking and working on accounting puzzles. At last, intellectual is seen when students actively participate in solving problems. Based on each characteristic's skills of the SAVI learning model, it can be seen that the SAVI learning model leads and is related to collaboration skills indicators. Besides, the SAVI learning model has the principle of working together to help the learning process so that, in this learning model, students work together in a group. In accordance with Zulfa's (2013) research, in the SAVI learning model, each students' group was more active together to solve cases. The SAVI learning model is a learning model that utilizes and empowers brain stimulation so that students can play an active role in finding a solution to solve problems. Further, to support 21st-century learning, innovation learning that utilizes technology is needed. Therefore, the SAVI learning model application is designed based on electronics (e-learning), which provides innovation to improve education quality (Maspaeni, Wibawa \& Yusuf, 2017). The e-learning-based SAVI learning model can improve learning activities outside of class hours, search for material individually, and discuss it in online classes (Kusumantara, Santyadipura, \& Sugihartini, 2017).

During the learning process, of course, the teacher needs learning media as a tool to provide information in order to achieve learning objectives (Anita, 2012). In this study, the SAVI learning model 
was assisted by learning media for accounting puzzles. It increased the questions' difficulty level, so that collaboration between students in groups was also high, and cases could be resolved quickly and accurately. When students answered one question wrongly, it would affect other answers, so students must work together to find other answers correctly and accurately. Learning media for accounting puzzles is an interactive and fun learning media that can involve students actively participating and working in groups well (Azam, 2012). In the finding answer process for accounting puzzles learning media, students must have a respectful attitude for others' opinions, help other students solve problems, and have effective communication during the discussion process (Risdayanti, 2019). These things are related to the collaboration skills' indicators, so it is hoped that collaboration skills can improve after using the accounting puzzle media.

As in research conducted by Zulfa (2013), the SAVI learning model made students more active in finding out ways to solve problems in groups, and there was an increase in the collaboration skills' percentage from cycle I and cycle II. The similarity with this research is that students in groups were more active in communicating to solve problems to increase their collaboration skills in each cycle. Another study carried out by Erida Reningsih (2013) explained that the SAVI learning model could improve students' collaboration skills, which could be seen during the learning process. Besides, students were active in working in groups to complete tasks. The highest percentage that experienced an increase was individual responsibility, and the lowest was interpersonal relationships. The similarity in this study is that the SAVI learning model application has increased for every aspect measured. Students were more active and wanted to listen to friends' opinions. Also, the highest increase was in individual responsibility. Relevant research was also put forward by Sumaryati, Joyoatmojo, Wiryawan, \& Suryani (2020) that a learning model utilizing a website could improve problem-solving skills and collaboration skills. It was because, in the learning model, students were actively taught to seek information related to everyday life so that they could solve problems. Students would then be assisted by tutors to achieve the expected competencies. In groups, they would also practice and discuss to solve cases, and finally, carried out self-assessment and other students' assessments for selfevaluation. The similarity of this research is that students were taught to play an active role in obtaining information through teachers and other students, solving problems in groups, and assessing other students in the group.

Based on the description above, teachers can improve class X AKL Wikarya Karanganyar Vocational High School students' collaboration skills by implementing the SAVI (Somatic, Auditory, Visual, and Intellectual) Learning Model assisted by e-learning-based Accounting Puzzle Media in the learning process.

\section{RESEARCH METHODS}

The research was conducted at Wikarya Karanganyar Vocational High School. The research subjects were 20 students of class X AKL 1 SMK Wikarya Karanganyar Academic Year 2019/2020. This research was a Classroom Action Research (CAR) employed to improve classroom's learning quality during the learning process. This study consisted of four stages in accordance with the research procedure, which began with the action planning stage, the action stage, the observation stage, and the reflection stage, which were carried out for two cycles. This study set the success target, namely the average percentage of collaboration skills' indicators that had to reach a good category of $62.50 \%$ (Rohim, 2012). If the research's success target was not achieved in Cycle I, it would be continued with cycle II and the next cycle for improvement until this study's objectives were achieved. The data collection techniques employed in this study were interviews and observations. Interviews were used to obtain information about the SAVI learning model assisted by e-learning-based Accounting Puzzles, whether it could improve students' collaboration skills. It was conducted with teachers and students of class X AKL 1 SMK Wikarya Karanganyar. Interviews with teachers were carried out directly at SMK 
Wikarya Karanganyar, while students were done online by contacting several students. Meanwhile, the observation was carried out to observe collaboration skills and the SAVI learning model application assisted by e-learning-based Accounting Puzzles shown during the learning process. Moreover, the collaboration skills' indicators measured were positive interdependence, face-to-face interactions, individual responsibility, interpersonal relationships, and group processes. Whereas the model implementation was assessed based on the SAVI learning model stages, covering the preparation stage, delivery stage, training stage, and result delivery stage. In the data collection implementation through online observations, each group would be observed by one observer, and an assessment between students was also carried out in the group to strengthen the observation results. The collaboration skills' observation results were in the form of observation sheets regarding the students' collaboration skill scores. It was then processed and presented in the form of a percentage, shown in Table 1. Meanwhile, the observation results on the SAVI learning model implementation were also presented in the form of a percentage for each stage. The data analysis technique used qualitative data and quantitative data. The qualitative data were analyzed using critical analysis techniques, namely identifying the weaknesses and strengths of student and teacher performance during the process of implementing the SAVI learning model assisted by e-learning-based Accounting Puzzles. The analysis results were utilized as a material for developing plans to improve the action implementation in the next cycle. Quantitative data were analyzed using comparative descriptive statistical techniques to investigate the collaboration skills' level in each cycle in collaboration skills' observation sheets.

\section{RESULTS AND DISCUSSION}

The results of the SAVI (Somatic, Auditory, Visual, and Intellectual) learning model application assisted by e-learning-based Accounting Puzzle (TTA) media in class X AKL 1 SMK Wikarya Karanganyar were carried out in two cycles. Each cycle consisted of an action planning stage, the action implementation stage, observation and interpretation stage, and analysis and reflection stage. The research results can be described as follows:

\section{Cycle I}

In the first cycle, the action planning stage was carried out by compiling the lesson plan (RPP) and preparing the Accounting Puzzles media and the observation sheet for the learning model implementation. The action implementation stage was conducted in accordance with the lesson plan (RPP), which referred to the SAVI learning model assisted by the e-learning-based media of Accounting Puzzles (TTA). Preliminary activities were done by conditioning students by 1) distributing link codes to join e-learning learning, 2) giving greetings, 3) leading prayer, 4) apperception, 5) conveying learning objectives, and 6) providing an overview learning design and explaining the SAVI learning model assisted by e-learning based Accounting Puzzles (TTA) media. Four core activities must be carried out in the SAVI learning model assisted by e-learning-based Accounting Puzzles (TTA) media: 1) The preparation stage through google meet, the teacher divided students into five groups. The teacher asked questions about the material to be studied, but no students answered, so that the teacher appointed students to answer questions. 2) In the delivery stage, the teacher explained the material regarding the adjusting journal in detail by providing examples for each journal entry that needed to be adjusted and asked students to practice working on the provided questions. 3) In the training stage, the teacher distributed question cards in the form of accounting puzzles through the WhatsApp group. Each group had to discuss and ensure that all groups sent answers to the teacher when the time was up. At this stage, each group discussed the case in the WhatsApp group via videocall. This online discussion was not supported by each individual's internet network, so that it was quite hampered. Also, some groups were silent without trying to discuss with friends in the group. 4) In the result delivery stage, the teacher again shared the link code for students to join the online class. The teacher asked each group to make a presentation, and other groups would respond if there were an incorrect answer. However, 
no students responded to the group that made the presentation; they were just silent and followed learning continuity. In closing activities, the teacher and students concluded the material for adjusting journals and reflected by analyzing the deficiencies in this meeting so that further improvements were made at the next meeting. The teacher ended the class with a prayer.

In the observation and interpretation stage, the observers investigated what happened when learning took place when using the e-learning-based SAVI learning model assisted by Accounting Puzzles (TTA). Then, they recorded what happened in learning to obtain accurate data for improvement in the next cycle. Based on observations, it was found that the following skills observations were found.

Table 1. Collaboration Skills' Observation Results

\begin{tabular}{llcc}
\hline No & Collaboration Skills Indicators & Pre-Action & Cycle I \\
\hline 1 & Positive interdependence & $42,14 \%$ & $57,5 \%$ \\
2 & Face to face indication & $43,06 \%$ & $59,17 \%$ \\
3 & Individual responsibility & $45,38 \%$ & $54,38 \%$ \\
4 & Interpersonal Relationships & $43,06 \%$ & $59,22 \%$ \\
5 & Group process & $43,51 \%$ & $58,33 \%$ \\
\hline Percentage Average & $43,52 \%$ & $57,72 \%$ \\
Category & Not Good & Sufficient \\
Outcome Indicators & $62,5 \%$ & Good \\
\hline
\end{tabular}

Based on Table 1 above, it could be seen that there was an increase in students' collaboration skills from pre-action to cycle I. The average percentage of students' collaboration skills was $43.52 \%$ in pre-action and increased to $57.72 \%$ in Cycle I. The lack of student collaboration skills was also proven by as many as 11 out of 20 students were included in the sufficient category with an average percentage of $54.87 \%$. Although the students' collaboration skills' percentage increased from pre-cycle to cycle I, it has not yet fulfilled the success achievement indicators, namely $62.5 \%$. Thus, further action was needed.

The analysis and reflection stages were carried out by discussing the problems obtained during observation between the teacher and the researches. Through reflection, the researchers would determine the decision to continue the cycle or stop. In cycle I, the students' collaboration skills were still low because they were still shy and hesitant to express their opinions. In online discussions through group WhatsApps, most students were more silent and worked on problems independently. Some students had high selfishness so that other students were reluctant to solve questions in groups. Some students were indifferent to the group, did not respect other students, did not understand friends, and did not ask again about the difficulties experienced by other students in the group. The reflection in cycle I was as follows: 1) the internet network was inadequate so that it made students got incomplete material. 2) The teacher did not explain in detail about the SAVI learning model application and how to work on accounting puzzles, so that the students felt confused. 3) Students tended to be passive when the teacher explained the material and had discussions, so that collaboration skills among students were still lacking. 4) Students preferred to be individual and paid less attention to friends. 5) Students' collaboration skills were only $57.72 \%$ and had not reached the achievement indicator of $62.5 \%$.

\section{Cycle II}

In cycle II, the shortcomings from the cycle I were improved. From cycle I, things that should be improved were instructions' emphasizing and re-explaining for solving questions in the form of Accounting Puzzles, making students more active in the learning process, making participants students 
were not awkward and embarrassed when asking or giving opinions, doing assignments in groups, and respecting other students.

Cycle II improvements were seen at the delivery stage; the teacher explained material about financial reports and asked some questions about students' understanding. In this condition, some students responded to questions without the need to be appointed by the teacher. It could also be seen at the training stage. Students already understood how to do questions in the form of accounting puzzles and did not experience difficulties. Besides, group discussions showed that students have already had the willingness to give opinions, better understood other students, and completed tasks given by teachers together. Even at the result delivery stage, when the teacher asked each group to make a presentation, they had voluntary representation without coercion. In this process, students were more appreciative of students who made presentations and were quite active in reinforcing inaccurate answers to groups that made presentations.

Based on the cycle II implementation, the observers observed what happens when learning took place using the e-learning-based SAVI learning model. The results obtained were 1) in the positive interdependence indicators, students already had the willingness to give opinions and tried to solve problems together, reminded or reprimanded friends when their friends did not help with group assignments. 2) In face-to-face interaction indicators, students were more aware of the groups' existence so that without being asked, they took the initiative to go online and made group video calls. In conducting the discussion, students also provided opportunities for their friends to give their opinions about the problems given by the teacher. 3) For individual responsibility indicators, students have discussed in groups to work on the teacher's questions so that individual responsibility in the group has improved. 4) Concerning interpersonal relationship indicators, students began to communicate openly and gave ideas about answers to the teacher's questions. Students also received ideas from other students to ensure whether the answers were as expected. Students also felt happy when the group has submitted the assignment to the teacher. 5) In group process indicators, students helped friends who were having difficulties and did it together. Students also united their opinions if the opinions given were different. In terms of presentations, other groups were quite active in reinforcing incorrect answers to the group presenting. Based on this description, students' collaboration skills could be said to have increased in cycle II. The increase in the observation results of students' collaboration skills in preaction, cycle I, and cycle II can be seen in Table 2, as follows.

Table 2. Collaboration Skills' Improvement

\begin{tabular}{llccc}
\hline No & Collaboration Skills Indicators & Pre-Action & Cycle I & Cycle II \\
\hline 1 & Positive interdependence & $42,14 \%$ & $57,5 \%$ & $71,67 \%$ \\
2 & Face to face indication & $43,06 \%$ & $59,17 \%$ & $73,13 \%$ \\
3 & Individual responsibility & $45,38 \%$ & $54,38 \%$ & $71,88 \%$ \\
4 & Interpersonal Relationships & $43,06 \%$ & $59,22 \%$ & $74,22 \%$ \\
5 & Group process & $43,51 \%$ & $58,33 \%$ & $73,33 \%$ \\
\hline \multirow{2}{*}{} & Percentage Average & $43,52 \%$ & $57,72 \%$ & $72,84 \%$ \\
& Category & Not Good & Sufficient & Good \\
& Outcome/Category Indicators & $62,5 \%$ & & Good \\
\hline
\end{tabular}

The improvement of student collaboration skills can also be seen in Figure 1, as follows. 


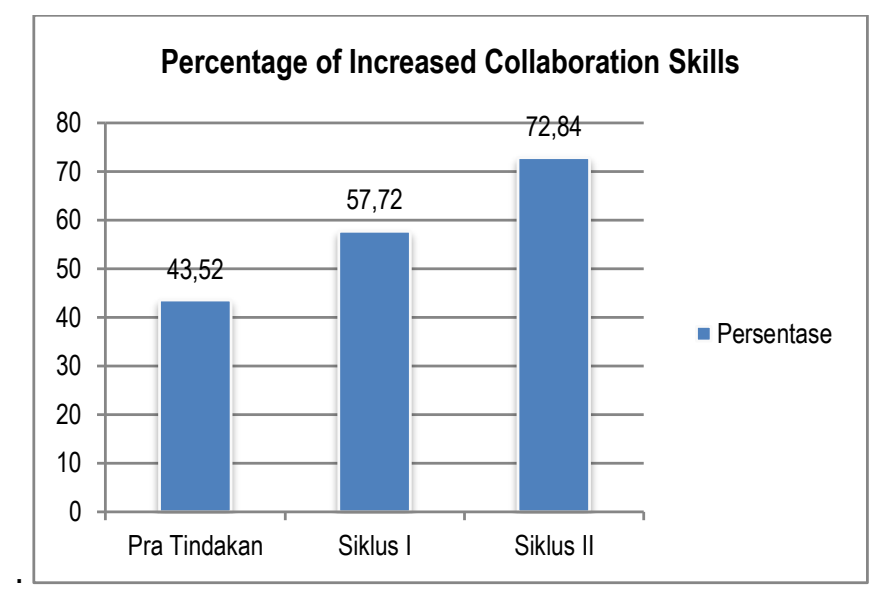

Figure 1. Percentage of Collaboration Skills' Improvement

Based on Table 2 and Figure 1 above, it could be seen that there was an increase in students' collaboration skills from pre-action, cycle I, and cycle II. Besides, the average percentage of students' collaboration skills was $43.52 \%$ in pre-action, increased to $57.72 \%$ in cycle I, and increased by $72.84 \%$ in cycle II. Another thing was also proven by as many as 16 out of 20 students were in a good category, with an average percentage of $71.81 \%$. It implied that they had met the research success's achievement indicators of $62.5 \%$ so that no further action was needed.

Based on the study's results, it was evident that the e-learning based SAVI (Somatic, Auditory, Visual, and Intellectual) learning model could improve collaboration skills. This study's results are supported by previous research conducted by Kusumantara, Santyadipura, \& Sugihartini (2017) that elearning could improve learning outcomes because students did not only listen, but they were actively involved in the learning process, as in the e-learning characteristics. The same thing was also stated in research conducted by Evin Zulfa (2013) that the SAVI learning model made students more active in finding out ways to solve problems in groups, but there were still some students who had selfish traits so that the indicators gave each other less information. It was not a barrier for the SAVI learning model to improve student learning outcomes and collaboration skills because overall, there was an increase in the collaboration skills' percentage from cycle I and cycle II. A study carried out by Erida Reningsih (2013) elucidated that the SAVI learning model could improve students' collaboration skills in every aspect. In the learning process, students were active in working in groups to complete tasks, could control their ego when dealing with others, listening to friends when giving opinions, and appeared active when expressing opinions. Moreover, 21st-century learning utilizing technology could help students in collaborative learning master the knowledge and solve problems given by teachers via the web (Wang \& Liu, 2009). The SAVI approach combined with technology is suitable for use in learning and can improve learning outcomes so that learning becomes quality, and students can find concepts online and are not quickly bored so they can play an active role in learning (Sari, Martono, \& Sawiji, 2019). Relevant research was also put forward by Sumaryati, Joyoatmojo, Wiryawan, \& Suryani (2020) that a learning model employing a website could improve problem-solving abilities and collaboration skills because students were actively taught to find information related to everyday life to solve problems and would practice discussing solving cases in groups.

Based on previous research and the present research, it could be concluded that the e-learningbased SAVI learning model was proven to improve collaboration skills. It could be seen that students were more active in communicating to solve problems, wanted to listen to other students' opinions, responded to questions given by the teacher, could express opinions in groups, played an active role to get information through teachers and other students, solved problems in groups, and conducted an assessment of other students. 


\section{CONCLUSION AND RECOMMENDATION}

From this research, it could be concluded that the application of the SAVI (Somatic, Auditory, Visual, and Intellectual) learning model assisted by e-learning-based Accounting Puzzles media could improve the collaboration skills of class X AKL 1 Wikarya Karanganyar Vocational High School students for the 2019/2020 academic year. It could be seen that there was an increase in the students' collaboration skills from cycle I and cycle II. Also, the percentage of the average skill in cycle I was $57.72 \%$ and increased to $72.84 \%$ in cycle II, categorized in the good category.

With the results obtained in this study, it is suggested to the teacher that the SAVI learning model application assisted by e-learning-based Accounting Puzzles media could provide an overview for teachers to make innovative learning so that learning is maximized, interesting, enjoyable, and able to improve students' collaboration skills. Suggestions for schools are to provide facilities and infrastructure to support learning activities, provide knowledge and insight to teachers about innovative learning so that learning is more interesting, and the need to conduct teacher performance evaluations while teaching in the classroom to be improved for better. Besides, suggestions for students are that they can be more active in working together in doing group assignments, understand friends, provide opportunities for other students, increase the responsibility sense for assignments given by the teacher, and help friends when they are experiencing difficulties.

\section{REFERENCES}

Anita, S. (2012). Media Pembelajaran. Surakarta: Yama Pustaka.

Azam, A. (2012). Penerapan Strategi Pembelajaran Crossword Puzlle Sebagai Upaya Meningkatkan Kemampuan Kerjasama Siswa Dalam Proses Pembelajaran Ekonomi Kelas VIII di Madrasah Tsanawiyah Negeri Bekonang Filial Kartasura Tahun Pelajaran 2012/2013. Jurnal Universitas Muhammadiyah Surakarta.

Daryanto, \& Karim, S. (2017). Pembelajaran Abad 21. Yogyakarta: Gava Media.

Ekaningtyas. (2014). Peningkatan Keterampilan Proses dan Hasil Subtema Tugasku Sehari -Hari di Rumah Menggunakan Model Pembelajaran SAVI Pada Siswa Kelas II SDN 1 Bolo. Jurnal Vol 4 (3).

Ginting, S. M., \& Amir. (2012). Penerapan Model Pembelajaran Somatic, Auditory, Visual Dan Intellectual (SAVI) Berbantu Media Computer Untuk Meningkatkan Kualitas Pembelajaran Kimia Fisika II. Vol. X. Jurnal Universitas Bengkulu.

Kusumantara, K. S., Santyadipura, G. S., \& Sugihartini. (2017). Pengaruh E-Learning Schoology Terhadap Hasil Belajar Simulasi Digital Dengan Model Pembelajaran SAVI. Jurnal Pendidikan Teknologi dan Kejuruan Vol. 14, No.02.

Maspaeni, Wibawa, B., \& Yusuf, H. (2017). Model Pembelajaran E-learning Berbasis Learning Managemen System. Jurnal Explore STMIK Mataram,7 (2).

Reningsih, E. (2013). Peningkatan Kemampuan Kerjasama Siswa Melalui SAVI (Somatic, Audiotory, Visualization, Intellectual) Pada Mata Pelajaran Pengolahan Makanan Kontinental Di SMK Sahid Surakarta. Jurnal Universitas Negeri Yogyakarta.

Redhana, I. W. (2019). Mengembangkan Keterampilan Abad Ke - 21 Dalam Pembelajaran Kimia. Jurnal Universitas Pendidikan Ganesha, 13 (I).

Risdayanti, M. (2019). Upaya Meningkatkan Keaktifan Dan Hasil Belajar Akuntansi Dengan Menggunakan Strategi Crossword Puzzle Pada Siswa Smk Negeri 1 Medan Tahun Ajaran 2018/2019. Jurnal Muhammadiyah Sumatera Utara. 
Rohim, F. (2012). Pembelajaran Fisika dengan Model SAVI pada Pokok Bahasan Kalor untuk Meningkatkan Kemampuan Kerjasama Siswa Kelas VII MTs Matholi'ul Huda Troso. Skripsi. Semarang: Universitas Negeri Semarang.

Sholihin. (2015). The Using of SAVI (Somatic, Auditory, Visual, and Intellectual) Technique In Improving The Students Vocabulary at The Seventh Grade Of SMP N 01 Monta Bima.

Sumaryati, S., Joyoatmojo, S., Wiryawan, S. A., \& Suryani, N. (2020). Potential of E-CoPAL Strategy to Improve Analytical Problem Solving and Teamwork Skills in Accounting Education. International Journal of Instruction, 13(2), 721-732.

Zulfa, E. (2013). Pembelajaran Fisika Dengan Eksperimen Terbimbing Berbasis SAVI (Somatis, Auditori, Visual, Intelektual) Untuk Meningkatkan Hasil Belajar Dan Keterampilan Kerjasama siswa. Jurnal Universitas Semarang.

How to cite: Putri, V F C., Sumaryati, S., \& Jaryanto. (2020). The SAVI Learning Model Application Assisted by ELearning-Based Accounting Puzzle Media to Improve Vocational School Students' Collaboration Skills. Teknodika, 18 (2), 156 - 164 DOI: https://doi.org/10.20961/teknodika.v18i2.43375 